\title{
28 Research Square \\ Experimental Determination of Effect of Bushfire on Erosion Development in Different Soil Types
}

\section{Emmanuel Emeka Arinze ( $\nabla$ emmanuel.arinze@mouau.edu.ng )}

Michael Okpara University of Agriculture https://orcid.org/0000-0002-2796-653X

\section{Benjamin Ekwueme}

University of Nigeria

Jesuborn Obimba-Wogu

Michael Okpara University of Agriculture

\section{Samuel Okeke}

Michael Okpara University of Agriculture

\section{Research}

Keywords: Bushfire, Soil erosion, Postfire management, rainfall simulation, Geoenvironmental engineering

Posted Date: March 1st, 2022

DOI: https://doi.org/10.21203/rs.3.rs-1390441/v1

License: (c) (1) This work is licensed under a Creative Commons Attribution 4.0 International License. Read Full License 


\section{Abstract}

Tropical forests are increasingly exposed to devastating bushfires leading to increased erosion. This work involve the study of effect of bushfire on erosion development. Four different soil samples from the study area were used for the study. In this study, the post-fire impacts of laboratory fire representing bushfire and subsequent rainfall simulation experiment representing postfire rainfall to evaluate short-term impact of fire on bare soil. The laboratory observations show that bushfire or wildfire affects the erodibility of different types of soil. When the soil under consideration contains meaningful amount of clay, initial exposure to heat tend to cement the soil sample, because clay minerals hardens on exposure to bush burning. However, it is generally observed that at 6 hours exposure to burning, the cementation is adversely affected leading to increased soil loss.

\section{Introduction}

Wild land fire and bushfire fires are increasing in frequency and magnitude, due to climate change and human activities respectively (Thomaz, 2021; Di Piazzo, 2007). Recent challenges and policy developments are opportunities for soil physicists and other soil erosion modellers to respond with more accurate assessments and solutions as to how to reduce soil erosion and how to achieve Zero Net Land Degradation (ZNLD) targets of 2030 (Panagos and Katsoyiannis, 2019). Therefore, determining the relationship between bushfire and erosion development is imperative in achieving ZNLD. Post-wildfire responses are basically transitory, incident, variable in space and time, dependent on intensity and severity, and involve multiple processes measured by different methods (Moody et al., 2013). Wildfires or forest fire are known to be one of the major causes of soil erosion, slope instabilities, land degradation, and a times debris flow (Martini et al., 2020; Staley et al., 2018; Gabet, 2014; Benito, 2014). These effects are felt both in temperate region and in the tropics (Lal, 1985; Malkinson and Wittenberg, 2011; Keesstra et. al., 2012).

On-site effects are particularly evident on agricultural land where redistribution of soil particle within the area, loss of soil from the area, the breakdown of soil crumb and the reduction in organic matter and nutrient leading to reduction of cultivable soil depth and soil fertility. Erosion also lead to decrease in soil moisture, leading to more drought more drought-prone environment. The resultant effect is a loss of fertility vis-à-vis productivity and increased expenditure on fertilizer. Many countries spend so much on fertilizer leading to increase in cost of agricultural products. According to Morgan (2005), only $22 \%$ of the earth's field of 14,900 million hectares is conceivably productive. Since this has to give $97 \%$ of the food supply, it is under rising constraint as global population continue to surge.

Off-site problems emanate from sedimentation downstream, reducing the capacity of watercourses, and drainage channels enhancing the risk of flooding, blocking irrigations canals, shortening the design life of reservoirs .Numerous hydroelectricity dams and irrigation projects have been rendered ineffective by erosion. Sediments have the potentials of increasing the levels nitrogen and phosphorus in water bodies leading to eutrophication. Erosion contribute to the weathering of soil aggregate into basic particles of 
sand, silt and clay. The process of breaking down of soil aggregate into primary particles results in the release of $\mathrm{CO}_{2}$ to the atmosphere, aiding green house effect.

Forest roads are often subject to intense runoff and erosion, and can be intensified by wildfires (Spanos et. al., 2010; Wittenberg, 2012; Lucas-Borja, and Zema, 2021). Their impacts on ecosystems are expected to increase in time due to changes in climate and land use (Girona-Garcia et al., 2021). It is therefore vital to mitigate the increased hydrological and erosive response after wildfires to maintain the sustainability of ecosystems. Forest in the tropics are regularly subjected to severe fire outbreak. Majorly, fire impact causes meaningful effect on soil bio physiochemical properties. It also leads to vegetation damage exposing the soil to erosion and land degradation (Shakesby, 2011). These effects depends on the density of vegetation; the severity, size and intensity of the fire; and predominant soil type (Keeley, 2009; Moody et al., 2013). Bushfire affects soil hydrology by breaking down the aggregated soil structure, decreasing moisture retention, development of water repellency (WR) and production of oxidized ash layer (DeBano, 2000; Mataix-Solera et al., 2011; Bodi et al., 2013). This in turn reduces erodibility of soil, making the soil susceptible to erosion. Many researchers have studied the causes, effect and extent of fire-triggered soil erosion ranging from laboratory studies to catchment studies (Moody et al., 2013), pointing to a common fact of increased soil erosion after bushfire or wildfire.

DeBano (2000) established that fire results to total vaporization of organic matter present in the surface soil and litter layers. The charred organic matter is partly vaporized into the atmosphere and the remaining part transferred as vapour, towards deeper soil layers where it condenses. Bushfire not only causes an increase in runoff due to the formation of hydrophobic layer, but also decreases of soil erodibility, as a result of destruction of organic matter (Prosser \& Williams, 1998).

Low intensity fires result to increase in runoff only for the first erosive rainfall season, while higher intensity fires lead to increased runoff for 2-4 years (Soto \& Diaz-Fierros, 1998; Inbar et al., 1998;Candela et al., 2005). Fire destroys organic layer in a soil rich in organic matter, whereas for soils less rich in organic matter the increase of erosion processes is mainly due to the destruction of the vegetation cover and its protective function (Inbar et al., 1998). The oxidation of soil organic content and reduced permeability, caused by soil hydrophobicity, affects erodibility.

The extent of organic matter vaporized at the surface and, the resulting quantity of hydrophobic substances depends on both fire intensity, fire duration and the organic substances present in the soil. DeBano (2000) stated that hydrophobic substances probably originate from aliphatic hydrocarbons, made up by different carbonyl groups with a high percentage of oxygen.

The vegetation cover serves as biofuel, so it directly influences the fire temperature attained in soil layers.

Bushfire affects the landscape by burning vegetation, depositing ash, influencing WR, and mechanically weathering boulders and bedrocks (Santi, 2013; Thomaz, 2018). Water repellency increases runoff and erosion (Robichaud and Hungerford, 2000; Wittenberg et al., 2011) whereas ash layer increases soil loss (Larsen et al., 2009; Bodi et al., 2013). Ash alters soil hydrological properties, increases water retention 
and reduces sediment movement (Cerda and Doerr, 2008). However, ash has the potentials of clogging soil voids, sealing the soil surface, and increasing surface erosion. The first post bushfire rainfall partly wash away the ash, while some penetrate into the soil viod (Larsen et al., 2009; Keesstra et al., 2014). The properties and extent of ash layer determine the duration and degree of surface soil protection (Woods and Balfour, 2010; Bodi et al., 2012). Considering the complicated dynamics, a very in-depth grasp of the ash-soil-water system interaction is vital in the immediate post-fire period for efficient management practices that will mitigate soil erosion development (Thomas et al., 2000; Smith et al., 2011). A variety of restoration strategies can be adopted, including natural regeneration (such as fire breaks, weed control, erosion control, topsoil replacement, peatland rewetting), enrichment cultivation (such as planting nursery-raised seedlings, direct seeding), commercial restoration (such as plantation forests, agroforestry), use of check dam and applying Engineering With Nature (EWN) principles (Scheper et al., 2021; Haring et al., 2021; González-Romero et al., 2019). Soil erosion estimation models are important for predicting fire impacts and planning post-fire emergency responses (Fernández and Vega, 2018; Chuvieco et al., 2014).

The technique used in this study is to model the controlled experiment of bush burning and using subsequent rainfall simulations to determine how the erodibility of the soil is affected.

\section{Materials And Method}

\subsection{STUDY AREA}

Soil samples (Clay, Top soil, sand and Laterite) were all collected from Umudike, Abia State, Nigeria. Umudike the study area is located within the tropical rainforest belt. Climate of the area is characterized by two main seasons; the rainy season and the dry season. The dry season from the dry northeasterly air mass of Sahara desert (Harmathan), while the rainy season originated from humid maritime air mass of Atlantic Ocean.

The rainy season spans from mid-April to mid-November while the dry season span from mid-November to mid-April. The rainy season is characterized by double maxima rainfall peaks in July and September with a short dry season of about three weeks between the peaks known as the August break.

The study area Umudike and its environment is located within the central parts of Ikwuano - Umuahia which lies within 5028'645N and 5034'645N and longitudes 7031'602E and 7034'661E as shown in Fig. 1.

\subsection{Properties of leaf litter and soil}

The leaf and bark of Mangifera indica, a common tree in South-Eastern Nigeria was collected during the rainy season of 2021. Four different soils sample which include clay, sand, laterite and loamy soils. The unsorted and disturbed soil was dried at $60^{\circ}$ for 24 hours and sieved into two aggregates to observe any differences relating to texture. After 24 hours of drying $1 \mathrm{~kg}$ of litter was placed on each soil sample. 


\subsection{Burning Treatments}

A container of dimension $(50 \times 25 \times 5 \mathrm{~cm}$ ) were prepared for the initial conditions used in the rainfall simulation. For each of the aggregate size classes, 2 boxes were prepared which were further subdivided into unburnt (control) and burnt treatments.

The burning test was carried out under controlled laboratory conditions. Each of the soil sample were subjected to heat for 0 (control), 2, 4 and 6 hours. The burning temperatures of $250-300^{\circ} \mathrm{C}$ were recorded using thermocouple.

\subsection{Rainfall simulation}

In this study, a portable rainfall simulator designed and constructed by Geoenvironmental Research Group of Department of Civil Engineering, Michael Okpara University of Agriculture Umudike was used. Rainfall simulation took place for 2 hours per sample of soil. The trays were filled to $4 \mathrm{~cm}$ with disturbed and dried sample. The soil box samples were subjected to a constant rainfall intensity of $30 \mathrm{~mm} \mathrm{~h}^{-1}$. The rainfall simulation experiment process was done twice for quality assurance. After every simulations experiment the trays are dried in a heater. Drainage and runoff were collected at interval of 8 min and 4 mins respectively, from which sediments concentrations were measured. The rainfall simulation in operation is shown in Fig. 2.

\subsection{Geotechnical properties of soil sample}

The specific gravity, natural moisture content, Atterberg limit and sieve analysis were carried out according to ASTM D854-10, ASTM D2216-10, ASTM D4318-03 and ASTM C136/C136-19 specifications respectively.

\section{Result And Discussions}

The basic geotechnical properties known as index tests were carried out as shown in Table 1. 
Table 1

Index properties of soils used for the study

\begin{tabular}{|lllll|}
\hline Property & Clay & Laterite & Sand & Top soil (Loamy) \\
\hline Specific gravity & 2.52 & 2.55 & 2.60 & 2.40 \\
\hline Natural Moisture Content (\%) & 10.0 & 8.3 & 2.60 & 2.40 \\
\hline Liquid limit (\%) & 58 & 49 & Non-plastic & 29 \\
\hline Plastic limits (\%) & 30 & 28 & Non-plastic & 20 \\
\hline Plasticity Index (\%) & 28 & 21 & Non-plastic & 9 \\
\hline Sand content (\%) & & & & \\
\hline Fine particle content (\%) & 58.5 & 64.0 & 98.36 & 50.0 \\
\hline Unified Soil Classification System & 41.5 & 36.0 & 1.65 & 50.0 \\
\hline
\end{tabular}

The soil loss was minimized for soils subjected to fire for two hours, as shown in Fig. 4. For soil heated for 4 hours, the decline continued, then increased again at the 6th hour of heating. After 2 hours of fire, the loamy soil had an increase of roughly $8 \%$ in soil loss. After 4 hours of heating, the soil loss increased by $20 \%$, then decreased by $41 \%$ after 6 hours of heating. In sandy soils, soil loss was minimized when they were heated for two hours. For the soils that had been heated for 4 hours, the decline continued. However, when soil was heated for 6 hours, there was a significant increase in soil loss. The lateritic soil recorded a near linear relationship between the hours of exposure to bushfire and increase in soil loss. In order words, as the time of exposure increases, the soil loss increases.

The unheated soil used as a control and soil exposed for 6 hours witnessed the most soil losses. This demonstrates that during 2 hours and 4 hours of heating, the heating resulted in the hardening of clay minerals in clay and loamy, minimizing soil loss; but, as the heating continued for 6 hours, the cohesiveness began to deteriorate, resulting in increasing soil loss. The energy of transformation-heat and light-causes some crystal structures to transition from one form to another at a specific temperature (Mitchell and Soga, 2005). The reason for this is because a crystal's maximum stability is at its crystallization temperature. The structural stability reduces as the temperature goes below the crystallization temperature. Furthermore, because the heating was done at the temperature at which adsorbed water is affected, the heating impacts the adsorbed water of the soil (Mitchell and Soga, 2005), affecting the soil characteristics.

Figure 5 demonstrates that sand had the most soil loss, while laterite had the least. Clayey, laomy, sandy, and lateritic soils recorded cumulative soil losses of $48.0,51.2,74.8$, and $37.6 \mathrm{~kg} / \mathrm{m}^{2} / \mathrm{hr}$, respectively. Because the geotechnical (index) properties in Table 1 reveal that the soil is not plastic, low erodibility of sand could be attributable to a lack of cohesiveness. Clay's cohesive characteristic and organic matter's colloidal qualities in loamy soil provided significant resistance to soil detachment in clay and loamy soil, 
respectively. Clay's cohesion provides resistance to soil separation, while coarse soil's large unit weight provides barrier to transportation. Table 1 demonstrates that the lateritic soil contains a significant amount of clay mineral and sand that has been combined together by nature. Laterite's synergistic blend of clay and quartz minerals resisted soil loss. Heat helped these combined features by hardening the cementitious tendency of clay in lateritic soil that was reinforced by coarse particles.

The greatest soil losses were reported for unheated soil used as a control and soil heated for 6 hours, as illustrated in Fig. 6 and as previously mentioned. This demonstrates that during 2 hours and 4 hours of exposure to burning, the heating caused the clay mineral in clay, loamy, and laterite to harden, minimizing soil loss; but, as the heating persisted for 6 hours, the cohesiveness began to deteriorate, resulting in increasing soil loss.

\section{Conclusions}

The erodibility of different types of soil is affected by bushfire or wildfire. When a soil sample contains a significant amount of clay, first heat exposure tends to cement the soil sample, since clay minerals harden when exposed to bush burning. However, after 6 hours of exposure to burning, the cementation begins to give way, resulting in significant soil loss.

As the temperature rises, the crystal structures of sand alter, resulting in a loss of adsorbed water in the soil, modifying its property in such a way that it substantially stimulated soil loss.

In the lateritic, fine and coarse soils are about equal. This could explain why it demonstrated a one-of-akind property in terms of the link between time of burning and soil loss, with one increasing as the other did.

Finally, it is important to note that the burning period of 6 hours is key, as this is the time when all of the soil samples showed significant soil loss. The implication is that if a bushfire or wildfire occurs, it should not be allowed to burn for more than 6 hours, if possible.

\section{Declarations}

- Availability of data and material: All the data used were available in the paper

- Competing interests: There is no competing interest in the paper

- Funding: Self funded, no external funding was received

- Authors' contributions: E.E Arinze:Conceptualization, Experimental design; B.N Ekwueme: Literature review; J. Obimba-Wogu:Experiment; S. I Okeke: Experiment

- Acknowledgements: N/A

\section{References}


1. ASTM C136/C136M (2019). Standard Test Method for sieve analysis of Fine and Coarse Aggregates.

2. ASTM D2216 (2010). Standard Test Methods for Laboratory Determination of Water of Soil and Rock by Mass.

3. ASTM D4318 (2003). Standard Test Methods for Laboratory Determination of Atterberg limits of soils.

4. ASTM D854 (2010). Standard Test Methods for Specific Gravity of Soil Solids by Water Pycnometer.

5. Benito, E., Varela, M.E. and Rodríguez-Alleres, M. (2014). Wildfire effects on soil erodibility in Galicia. Cuadernos de Investigación Geográfica, 40 (2): 353.

6. Bodí, M.B., Doerr, S.H., Cerdà, A., Mataix-Solera, J. 2012. Hydrological effects of a layer of vegetation ash on underlying wettable and water repellent soil. Geoderma 191, 14-23..

7. Bodí, M.B., Muñoz-Santa, I., Armero, C., Doerr, S.H., Mataix-Solera, J., Cerdà, A. 2013. Spatial and temporal variations of water repellency and probability of its occurrence in calcareous Mediterranean rangeland soils affected by fires. Catena 108, 14-25.

8. Candela, A., Aronica, G. \& Santoro, M. (2005) Effects of forest fires on flood frequency curves in a Mediterranean catchment. Hydrol. Sci. J. 50(2), 193-206.

9. Cerdà, A., Doerr, S.H. 2008. The effect of ash and needle cover on surface runoff and erosion in the immediate post-fire period. Catena 74, 256-263.

10. Chuvieco, E., Martínez, S., Román, M.V., Hantson, S., Pettinari, L.M. (2014). Integration of ecological and socio-economic factors to assess global vulnerability to wildfire, Global Geology and Biogeography, 23(2): 245-258.

11. DeBano, L.F., 2000. The role of fire and soil heating on water repellency in wildland environments: a review. Journal of Hydrology 231-232, 195-206.

12. Di Piazza, G.V., Di Stafano, C. and Ferro, V. (2007). Modelling the effects of a bushfire on erosion in a Mediterranean basin, Hydrological Sciences Journal, 52 (6): 1253-1270.

13. Fernández, C. and Vega, J.A (2018). Evaluation of the rusle and disturbed wepp erosion models for predicting soil loss in the first year after wildfire in NW Spain. Environmental Research, 165: 279-285.

14. Girona-García, A., Vieira, D.C. S., Silva, J., Fernández, C., Robichaud, P.R. and Keizer, J.J. (2021). Effectiveness of post-fire soil erosion mitigation treatments: A systematic review and meta-analysis. Earth-Science Reviews, 217: 103611.

15. González-Romero, J., Lucas-Borja, M.E., Plaza-Álvarez, P.A., Sagra, J. Moya, D. and De Las Heras, J. (2019). Short-term effects of postfire check-dam construction on ephemeral stream vegetation in a semiarid climate of SE Spain, Science of The Total Environment,671:776-785.

16. Haring, C.P., Altmann, G.L., Suedel, B.C. and Brown, S.W. (2021). Using Engineering With Nature ${ }^{\circledR}$ $\left(E W N^{\circledR}\right)$ principles to manage erosion of watersheds damaged by large-scale wildfires. Integrated Environmental Assessment and Management, 142/274 (Environmental Sciences). 
17. Inbar, M., Tamir, M., Wittenberg, L. 1988. Runoff and erosion processes after a forest fire in Mount Carmel, a Mediterranean area. Geomorphology 24, 17-33.

18. Keeley, J.E. 2009. Fire intensity, fire severity and burn severity: a brief review and suggested usage. International Journal of Wildland Fire 18, 116-126.

19. Keesstra, S.D., Maroulis, J., Argaman, E., Voogt, A. and Wittenberg, L. (2014). Effects of controlled fire on hydrology and erosion under simulated rainfall. Cuadernos de Investigación Geográfica, 40(2): 269.

20. Keesstra, S.D., Wittenberg, L., Voogt, A., Argaman, E. and Malkinson, D. (2012). Post-fire effects on hydrological and erodibility factors in a simulated burn and rainfall experiment. Geophysical Research Abstracts, 2012.

21. Lal, R. (1985). Soil erosion and sediment transport research in tropical Africa, Hydrological Sciences Journal, 30(2): 239-256.

22. Larsen, I.J., MacDonald, L.H., Brown, E., Rough, D., Welsh, M.J., Pietraszek, J.H., Libohova, Z., De Dios Benavides-Solorio, J., Schaffrath, K. 2009. Causes of Post-Fire Runoff and Erosion: Water Repellency, Cover, or Soil Sealing? Soil Science Society of America Journal 73 (4), 1393-1407.

23. Lucas-Borja, M.E. and Zema, D.A. (2021). Rill erosion in unpaved and rock-paved roads after wildfire in a mediterranean forest. Geosciences, 11(2):79.

24. Malkinson, D., Wittenberg, L. 2011. Post fire induced soil water repellency-Modeling short and longterm processes. Geomorphology 125, 186-192.

25. Martini, L., Faes, L., Picco, L., Iroumé, A., Lingua, E. Garbarino, M. and Cavalli, M. (2020). Assessing the effect of fire severity on sediment connectivity in central Chile. Science of The Total Environment, 728: 139006.

26. Mataix-Solera, J., Cerdà, A., Arcenegui, V., Jordán, A., Zavala, M.L. 2011. Fire effects on soil aggregation: A review. Earth-Science Reviews 109, 44-60.

27. Mitchell, J.K. and Soga, K. (2005). Fundamentals of soil behaviour. $3^{\text {rd }}$ Ed. John Willey \& Sons, Inc.

28. Moody, J.A., Shakesby, R.A.,Robichaud, P.R., Cannon, S.H. and Martin, D.A (2013). Current research issues related to post-wildfire runoff and erosion processes. Earth-Science Reviews, 122: 10-37.

29. Morgan, R.P.C. (2005). Soil erosion and conservation. $3^{\text {rd }}$ Ed. Willey-Blackwell.

30. Panagos, $P$ and Katsoyiannis, A. (2019). Soil erosion modelling: The new challenges as the result of policy developments in Europe. Environmental Research, 172: 470-474.

31. Prosser, I. P. \& Williams, L. (1998). The effect of wildfire on runoff and erosion in native Eucalyptus forest. Hydrol. Processes 12, 251-265.

32. Robichaud, P.R., Hungerford, R.D. 2000. Water repellency by laboratory burning of four northern Rocky Mountain forest soils. Journal of Hydrology 231-232, 207-219.

33. Santi, P.M and Rengers, F.K (2013). Wildfire and Landscape Change, Treatise on Geomorphology, 13: 262-287. 
34. Scheper, A.C., Verweij, P.A. and Kuijk, M.V. (2021). Post-fire forest restoration in the humid tropics: A synthesis of available strategies and knowledge gaps for effective restoration. Science of The Total Environment, 771:144647.

35. Shakesby, R.A. 2011. Post-wildfire soil erosion in the Mediterranean: Review and future research directions. Earth-Science Reviews 105(3-4), 71-100.

36. Smith, H.G., Sheridan, G.J., Lane, P.N.J., Bren, L.J. 2011. Wildfire and salvage harvesting effects on runoff generation and sediment exports from radiata pine and eucalypt forest catchments, southeastern Australia. Forest Ecology and Management 261, 570-581.

37. Soto, B. \& Diaz-Fierros, F. (1998) Runoff and soil erosion from areas of burnt scrub: comparison of experimental results with those predicted by the WEPP model. Catena 31, 257-270.

38. Spanos, I., Raftoyannis, Y., Platis, P., Xanthopoulou, E. 2010. Post-fire management and recovery of a pine forest in Greece. Web Ecology 10, 27-31.

39. Staley, D.M., Tillery, A.C., Kean, J.W., McGuire, L.A., Pauling, H.E., Rengers, F.K. and Smith.J.B. (2018). Estimating post-fire debris-flow hazards prior to wildfire using a statistical analysis of historical distributions of fire severity from remote sensing data. International Journal of Wildland Fire 27(9) 595-608.

40. Thomas, A.D., Walsh, R.P.D., Shakesby, R.A. 2000. Post-fire forestry management and nutrient losses in eucalyptus and pine plantations, northern Portugal. Land Degradation and Development 11, 257271.

41. Thomaz, E.L. (2018). Interaction between ash and soil microaggregates reduces runoff and soil loss. Science of The Total Environment, 625:1257-1263.

42. Thomaz, E.L. (2021). Effects of fire on the aggregate stability of clayey soils: A meta-analysis. EarthScience Reviews, 221:103802.

43. Wittenberg, L. 2012. Post-fire soil ecology: Properties and erosion dynamics. Israel Journal of Ecology and Evolution 58, 151-164.

44. Wittenberg, L., Malkinson, D., Voogt, A., Leska, D., Argaman, E., Keesstra, S.D. 2011. The relative importance of soil water repellency in determining runoff-infiltration processes in burned Mediterranean forest soils. 3rd International meeting on Fire Effects on Soil Properties, University of Minho, Portugal.

45. Woods, S.W., Balfour, W.N. 2010. The effects of soil texture and ash thickness on the post-fire hydrological response from ash-covered soils. Journal of Hydrology 393, 274-286.

\section{Figures}




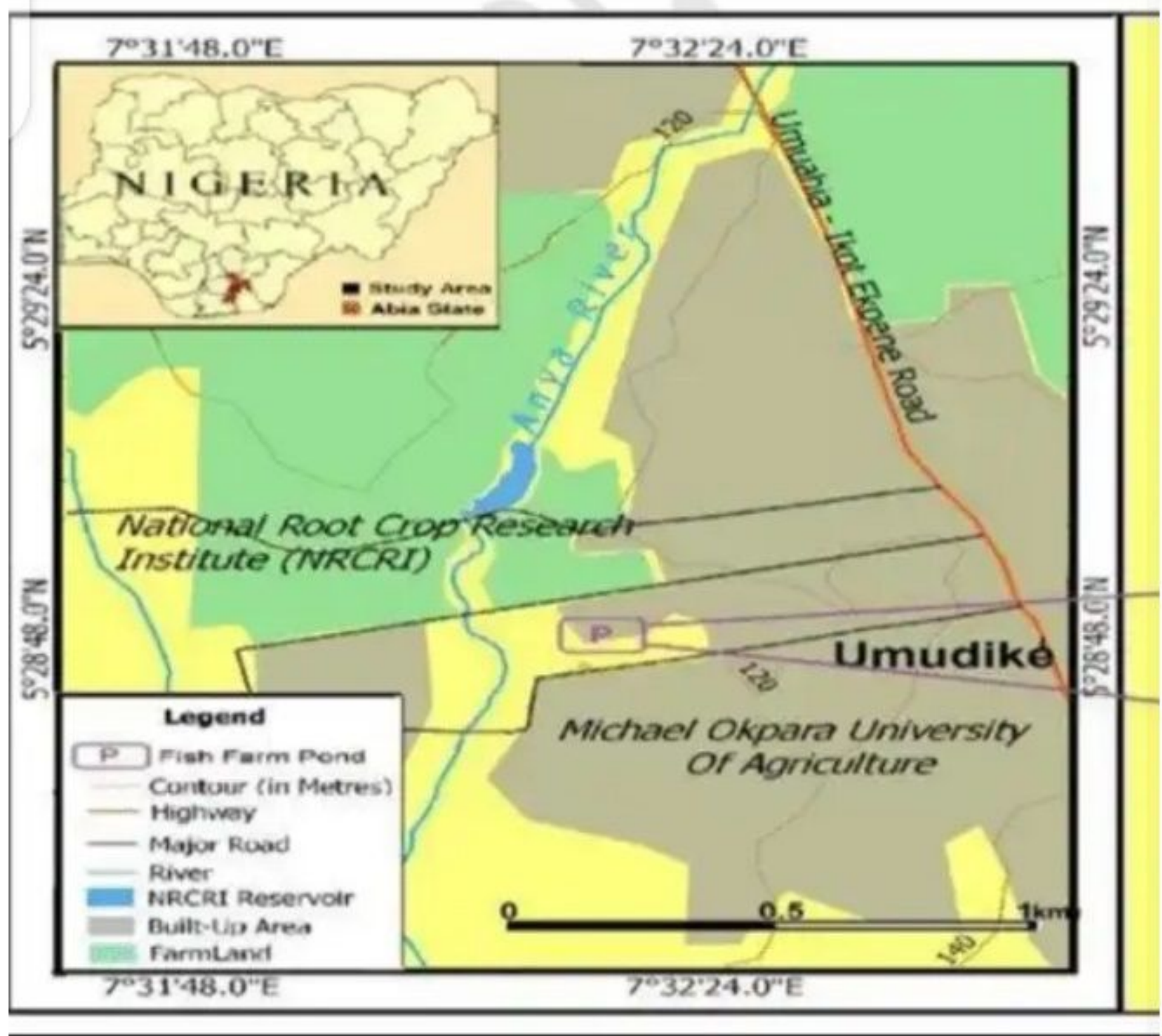

Figure 1

Geographical map of study area 


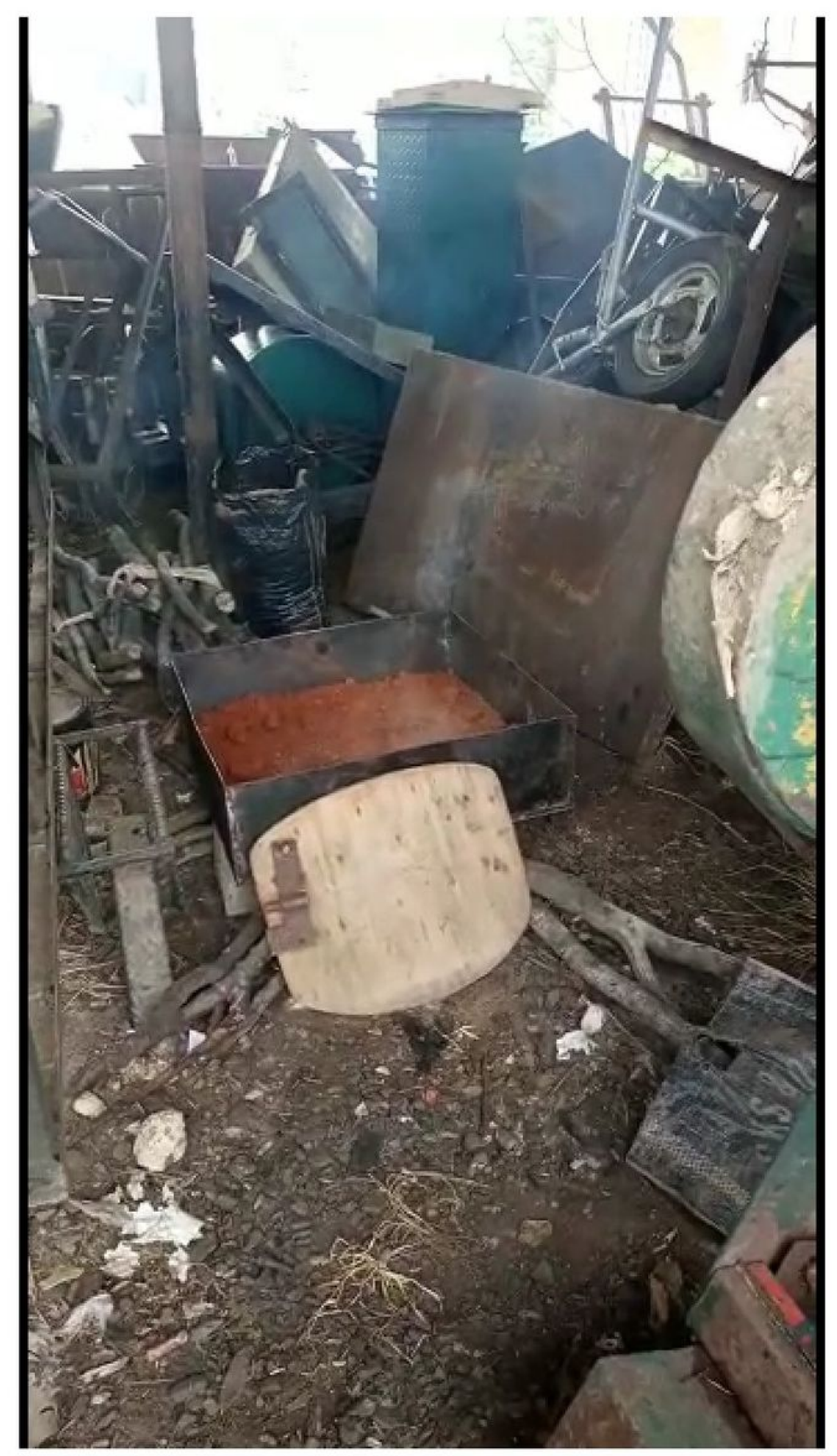

Figure 2

Heat treatment of the soil 


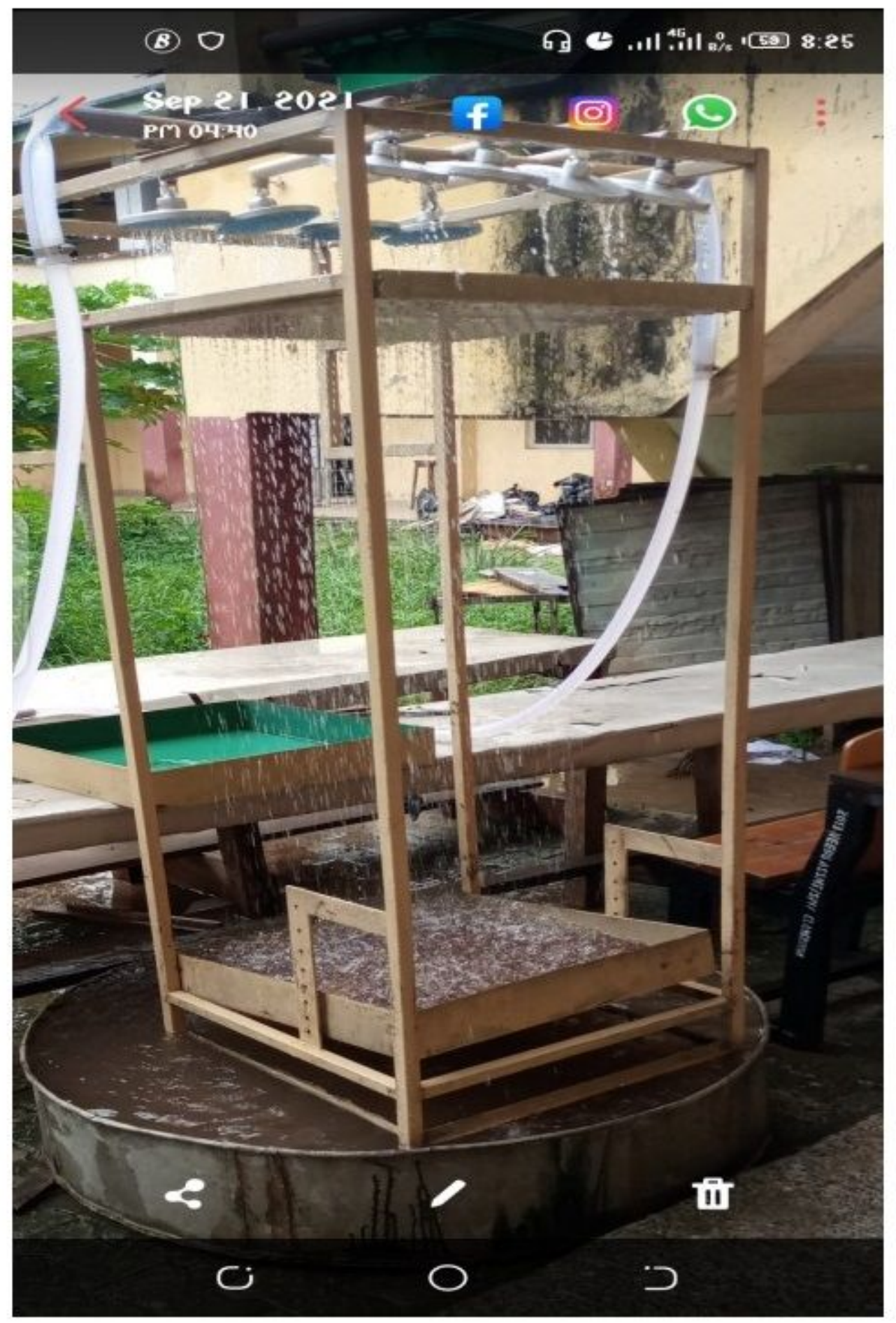

Figure 3

Rainfall simulation test of the heat treated soil 


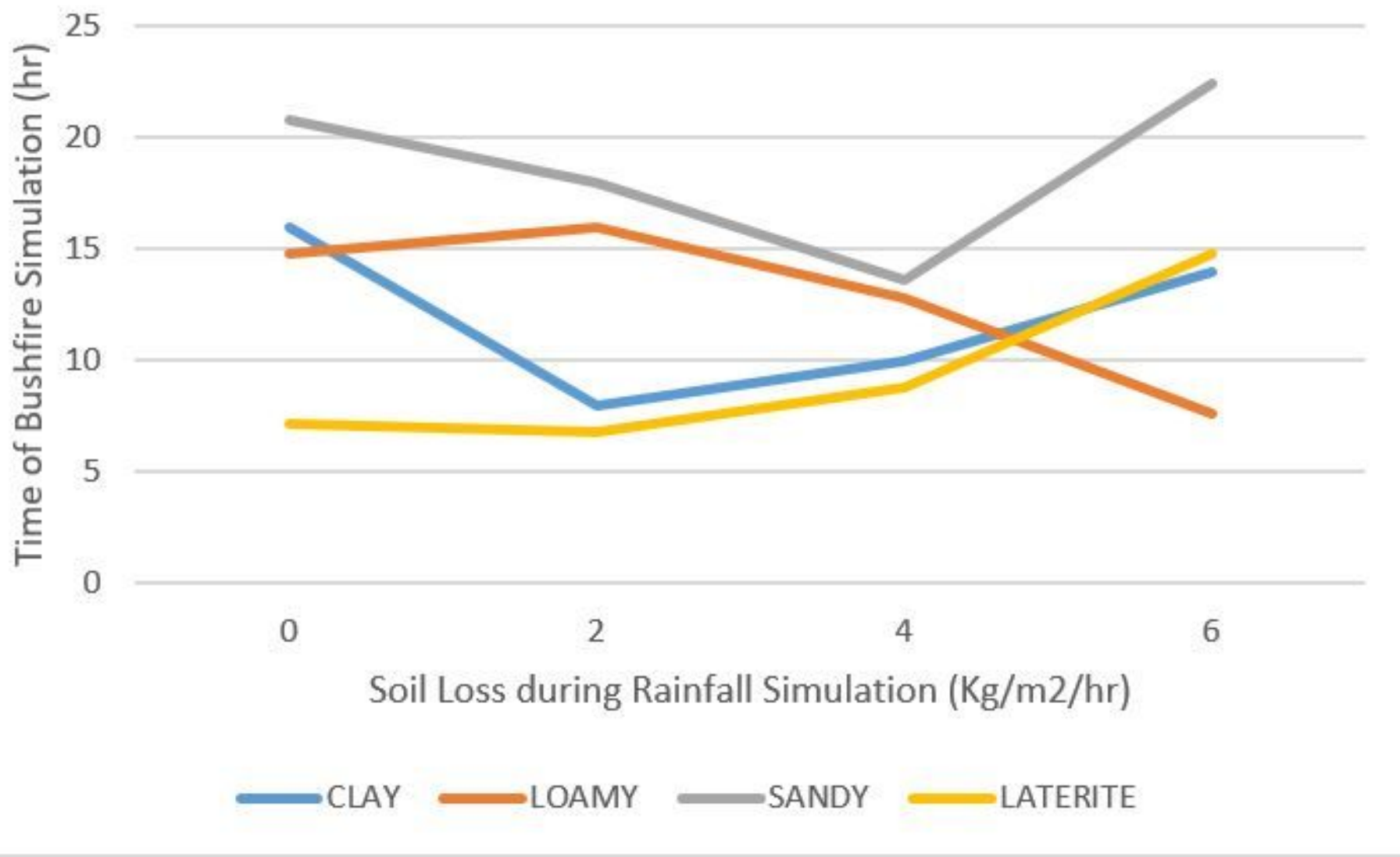

Figure 4

Time of heating vs soil loss. 


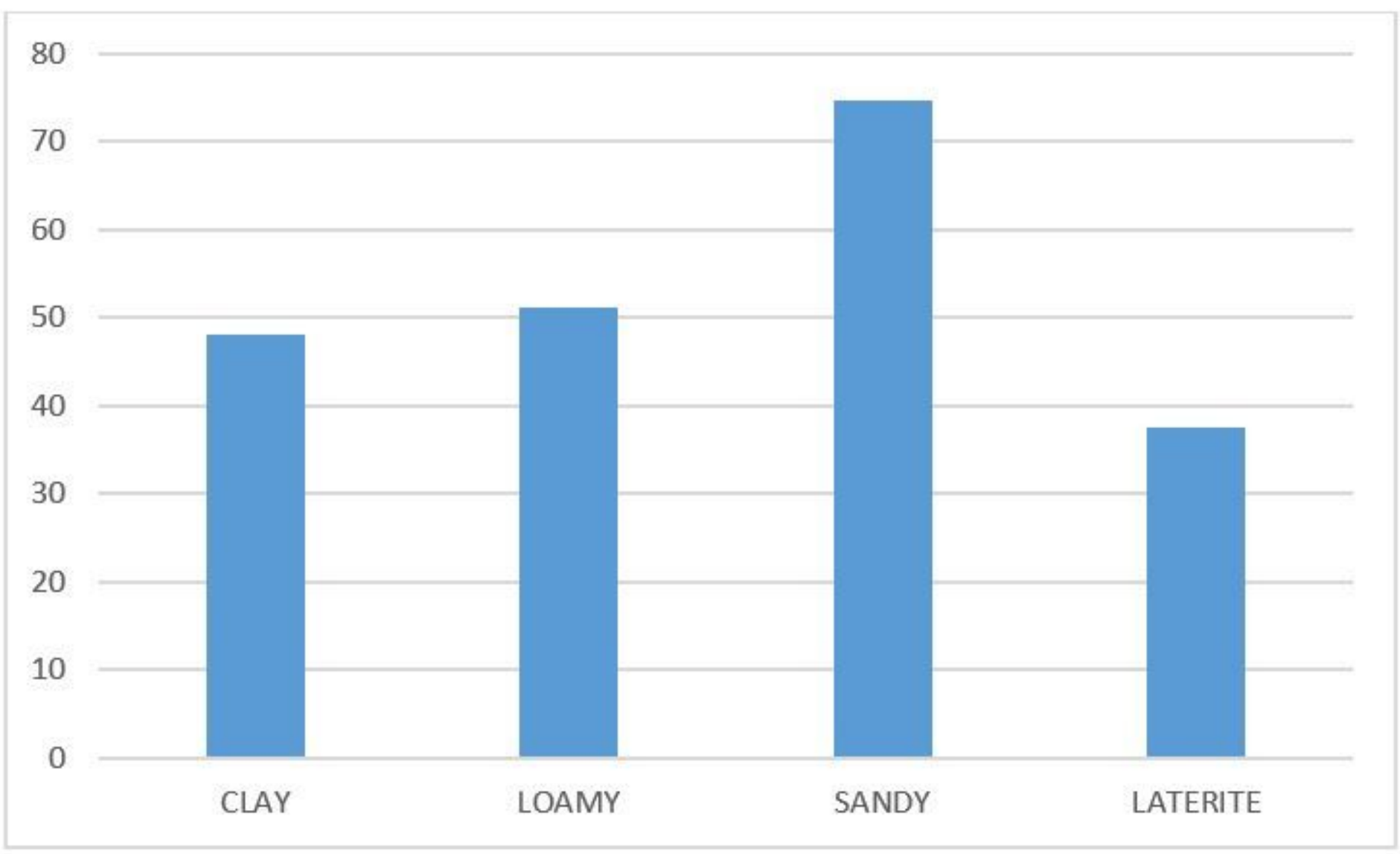

Figure 5

Cumulative soil loss in each sample 


\section{CUMMULATIVE SOIL LOSS}

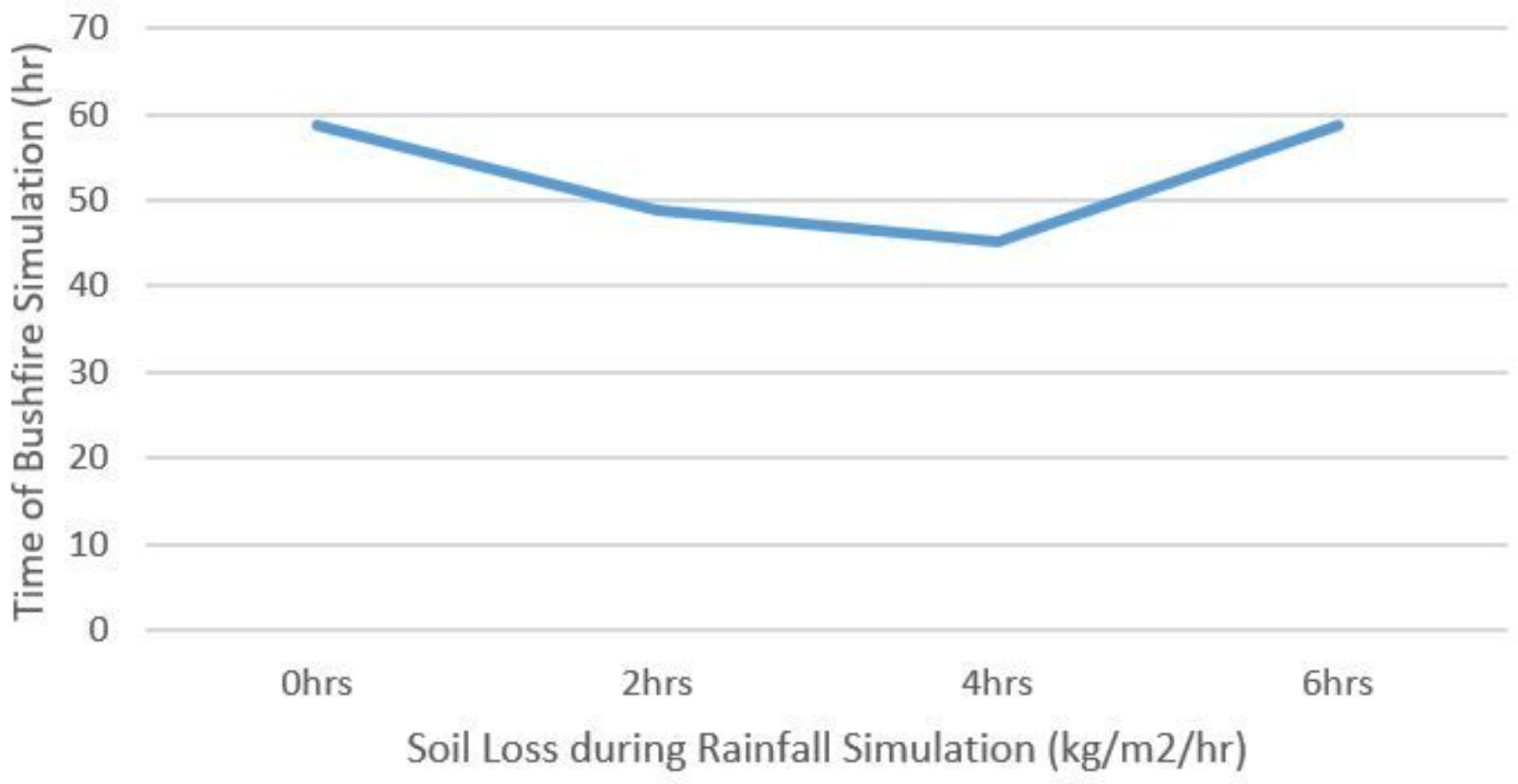

Figure 6

Time of heating vs soil loss 